\title{
Pemanfaatan probiotik dalam cookies labu kuning sebagai strategi pengembangan produk biskuit fungsional
}

\author{
The utilization of probiotics in pumpkin cookies as a development strategy of a \\ functional biscuit product \\ Monica Ageng Wardani ${ }^{1 *}$, Lusiawati Dewi ${ }^{1)}$ \\ ${ }^{1}$ Program Studi Biologi, Universitas Kristen Satya Wacana, Salatiga, Jawa Tengah \\ *Email : monicaageng23@gmail.com \\ Informasi Artikel: \\ Dikirim: 03/07/2021; disetujui: 25/08/2021; diterbitkan: 28/09/2021
}

\begin{abstract}
Background: Pumpkin (Curcubita moschata Durch) is a type of vegetable that can be easily damaged like cracked or scratched as the harvesting or post-harvesting time. Those imperfect pumpkins will be rotten in a short time so that they cannot be sold in the market. Therefore, they need to be processed into a durable functional food in the form of cookie; the pumpkin is as the main ingredient for the dough and Lactobacillus $s p$, the probiotics bacteria is added into it. Research purposes: The aim is to find out the exact concentration of the coating materials' combination and the viability of probiotics which is encapsulated in the maltosedextrin. Method: The coating materials' combination is examined through encapsulation process using $10 \%$ skimmed milk with three different precentage of maltodextrin i.e. $10 \%, 15 \%$ and $20 \%$. The viability test was carried out using the spread plate method and then analyzed using the Colony Forming Unit and Viability (\%) calculation method. Results and Discussion: The coating materials' combination at concentration of $10 \%$ skimmed milk $+10 \%, 15 \%$ and $20 \%$ maltodextrin produce $84 \%, 90 \%$ and $98 \%$ cells' viability. This shows that the use of those combinations can maintain the viability of the bacteria from the heat during the baking process at $180^{\circ} \mathrm{C}$ for 13 minutes. Conclusion: The microencapsulation of Lactobacillus achidopilus and Bifidobacterium logum with $10 \%$ skimmed milk $+20 \%$ maltodextrin resulted in the best viability as much as $98 \%$ viability cells. The higher the maltodextrin amount, the greater the bacterial's viability is.
\end{abstract}

Keywords: cookies, encapsulation, pumpkin, probotic, viability.

\begin{abstract}
ABSTRAK
Latar belakang: Labu kuning (Curcubita moschata Durch) merupakan tipe sayuran yang mudah rusak disebabkan oleh pasca panen atau proses distribusi. Sehingga perlu diolah agar memiliki daya simpan yang lama. Pada penelitian ini, labu kuning dimanfaatkan sebagai bahan dalam pembuatan olahan pangan fungsional dalam bentuk makanan ringan yaitu cookies labu kuning. Agar cookies labu kuning menjadi pangan fungsional maka perlu ditambahkan bakteri probiotik Lactobacillus sp. Tujuan penelitian: Penelitian ini bertujuan untuk mengetahui konsentrasi kombinasi bahan penyalut yang baik untuk pembuatan produk cookies probiotik dan untuk mengetahui viabilitas probiotik yang terenkapsulasi maltosedekstrin dalam cookies labu kuning. Metode: Sampel yang digunakan adalah cookies labu kuning dengan penambahan probiotik yang melalui proses enkapsulasi menggunakan kombinasi bahan penyalut susu skim $10 \%$ dan maltodekstrin $10 \%, 15 \%$ dan $20 \%$. Uji viabilitas dilakukan dengan
\end{abstract}


metode spread plate dan dianalisis dengan metode perhitungan CFU (Coloni Forming Unit) dan Viabilitas (\%). Hasil dan pembahasan: Kombinasi bahan penyalut pada konsentrasi $10 \%$ susu skim + maltodekstrin $10 \%, 15 \%$ dan $20 \%$ menghasilkan viabilitas sel $84 \%$, 90\% dan 98\%. Hal ini menunjukkan bahwa penggunaan kombinasi bahan penyalut tersebut dapat mempertahankan viabilitas bakteri dari panas akibat proses pemanggangan dengan oven pada suhu $180^{\circ} \mathrm{C}$ selama 13 menit. Kesimpulan: Mikroenkansulasi Bakteri Lactobacillus achidopilus dan Bifidobacterium logum dengan kombinasi penyalut konsentrasi $10 \%$ susu skim $+20 \%$ maltodekstrin menghasilkan viabilitas terbaik yaitu viabilitas sel $98 \%$. Hal ini menunjukkan bahwa semakin tinggi penambahan maltodekstrin yang dikombinasikan dengan susu skim 10\%, menghasilkan viabilitas sel bakteri yang tinggi.

Kata kunci: cookies, enkapsulasi, labu kuning, probiotik, viabilitas.

\section{PENDAHULUAN}

Labu kuning (Curcubita moschata Durch) merupakan salah satu komoditas dengan hasil panen yang cukup tinggi di Indonesia. Secara spesifik di pulau Jawa, hasil panen labu kuning pada tahun 2011 mencapai 150.000 ton/tahun (Mustika \& Kartika, 2020). Salah satu wilayah yang memiliki produksi labu kuning berlimpah terletak di Kecamatan Getasan, Kabupaten Semarang, Jawa Tengah. Produksi labu kuning di Kecamatan Getasan terus mengalami peningkatan yaitu dari 400 ton di tahun 2006 menjadi 950 ton di tahun 2014. Meskipun demikian, pada saat panen raya, banyak labu kuning yang rusak karena tidak laku terjual akibat rendahnya harga (Setyowati \& Khomah, 2016). Labu kuning diketahui memiliki masa simpan yang lama, akan tetapi jika kulit luarnya terbentur atau rusak akan mempengaruhi sifat biologis pada labu. Kerusakan labu umumnya disebabkan oleh penanganan pascapanen yang masih secara konvensional, misalnya di pasar tradisional yang hanya diletakkan begitu saja dan jika dikemas hanya menggunakan wadah seperti kotak kayu atau keranjang yang hanya berfungsi untuk menjaga dari benturan (Hamidah, 2015).

Pemilihan makanan saat ini tidak hanya berdasarkan kandungan gizi dan kelezatannya saja, namun cenderung mengarah pada pemilihan makanan sehat yang dapat memberikan kebutuhan dasar tubuh dan memenuhi fungsi gizi. Olahan pangan yang mampu memberikan kebutuhan gizi dan juga senyawa aktif lain yang bermanfaat bagi tubuh disebut sebagai pangan fungsional. Pemanfaatan pangan fungsional yang berkhasiat bagi kesehatan saat ini telah menjadi gaya hidup masyarakat modern (Kusumayanti, Hanindito, \& Mahendrajaya, 2016).

Inovasi pangan fungsional telah dilakukan dengan mengembangkan berbagai jenis makanan, termasuk makanan ringan. Salah satu jenis makanan ringan yang potensial dikembangkan menjadi pangan fungsional adalah kue kering atau cookies. Cookies dikenal sebagai snack siap konsumsi yang banyak digemari oleh berbagai kalangan usia terutama anak-anak di seluruh dunia. Cookies di Indonesia seringkali dikonsumsi sebagai kudapan sehari-hari dan telah menjadi "tradisi" untuk menyajikan cookies di hari-hari besar seperti Idul Fitri dan Natal. Makanan ringan ini digemari karena proses produksinya yang sederhana, tahan lama, dan berpotensi mengandung berbagai nutrisi. Cookies dapat dibuat dari berbagai jenis tepung, namun pada umumnya cookies dibuat dari tepung terigu (Hawa, Satheesh, \& Kumela, 2018). Saat ini banyak dikembangkan cookies dengan berbagai bahan tambahan untuk meningkatkan nutrisinya. Salah satunya adalah inovasi cookies labu kuning. Cookies labu kuning memiliki berbagai kandungan nutrisi yang berguna bagi tubuh. Penelitian Mustika dan Kartika (2020) menunjukkan bahwa dalam 100 gr cookies labu kuning mengandung protein 4,79 gr, lemak 40,87 gr, karbohidrat 50,19 gr, serat 21,42 gr, dan 
energi 587,72 kcal (Mustika \& Kartika, 2020).

Seiring dengan perkembangan budaya modern dalam masyarakat dan adanya pandemi Covid-19, kesadaran masyarakat akan konsumsi makanan sehat yang berkontribusi dalam meningkatkan daya tahan tubuh juga meningkat. Probiotik merupakan salah satu produk pangan fungsional yang apabila dikonsumsi dapat membantu meningkatkan daya tahan tubuh dan meningkatkan toleransi usus terhadap laktosa sehingga alergi terhadap produk susu dapat berkurang (Widiyaningsih, 2011). Probiotik didefinisikan sebagai mikroorganisme yang bila dikonsumsi dalam jumlah tertentu dapat memberikan manfaat kesehatan (Kusumayanti, Hanindito, \& Mahendrajaya, 2016). Konsumsi probiotik di Indonesia umumnya dalam bentuk minuman berbasis susu seperti yoghurt, kapsul ataupun tablet. Namun, agar probiotik dapat menjangkau lebih banyak konsumen, perlu dikembangkan produk probiotik dalam bentuk lain. Oleh karena itu, penelitian ini ingin memanfaatkan probiotik dalam cookies labu kuning sebagai inovasi pangan fungsional yang memanfaatkan komoditas lokal. Salah satu kendala yang dihadapi dalam penambahan probiotik dalam cookies adalah rendahnya viabilitas probitik yang terpapar suhu tinggi. Oleh karena itu, diperlukan bahan yang dapat melindungi probiotik dari pengaruh lingkungan sehingga tetap viabel dan bermanfaat bagi tubuh. Maltodekstrin merupakan bahan yang banyak dimanfaatkan sebagai media enkapsulasi bakteri yang banyak digunakan dalam industri makanan. Bahan ini memiliki beberapa kelebihan seperti bersifat higroskopis, mudah dicerna, tidak berasa, tidak bersifat toksik, dan dapat membentuk kristal (Husniati, 2009).

Maltodekstrin dipilih sebagai medium enkapsulasi probiotik karena memiliki titik didih yang tinggi yaitu $240^{\circ} \mathrm{C}$ (Puspita \& Samalukang, 2017) dan mampu meningkatkan viabilitas bakteri pada $\mathrm{pH}$ rendah (Samedi \& Charles, 2019) sehingga diperkirakan dapat mempertahankan viabilitas probiotik apabila diaplikasikan dalam cookies labu yang memerlukan pemanasan.

Penelitian ini bertujuan untuk mengetahui konsentrasi kombinasi bahan penyalut yang baik untuk pembuatan produk cookies probiotik dan untuk mengetahui viabilitas probiotik yang terenkapsulasi maltosedekstrin dalam cookies labu kuning.

\section{METODE}

\section{Bahan}

Bahan yang digunakan antara lain, labu kuning yang diperoleh dari pasar Getasan Kopeng Kabupaten Semarang, probiotik (Synbio, PT. KALBE FARMA Tbk, Bekasi- Indonesia), maltodekstrin (Sigma-Aldirch), Medium NA/ Nutrient Agar (Derajat Pro Analisis, Merck, Jerman), Medium NB/ Nutrient Broth (Derajat Pro Analisis, Merck, Jerman), Susu Skim (Derajat Pro Analisis, Merck, Jerman), Aquades. Tepung protein (Cakra Kembar), tepung labu kuning, susu bubuk (dancow), garam, baking powder, pewarna makanan, salted butter, gula pasir, brown sugar, telur, susu cair, vanilla pasta.

\section{Alat}

Alat yang digunakan antara lain, dehidrator (Maksindo, LT-85, Indonesia), herba grinder (Maksindo, MKS-ML 100, Indonesia), neraca analitik dengan ketelitian 0,01 gr (Shimadzu, TX 323L, Jepang), statif, spatula, termometer susu, hotplate (Thermolyne, Nouva II, Amerika Serikat), magnetic stirrer (Thermolyne, 846720-26, Amerika Serikat), gelas beker (Pyrex, Inggris), erlenmeyer (Pyrex, Inggris), tabung reaksi (Pyrex, Inggris), botol kaca, alumunium foil, cling wrap, freezer (LG, GN-V04RL, Indonesia), centrifuge (Hettich Centrifugen, EBA 20, Jerman), kuvet kuarsa, spektrofotometer UV-VIS (Genesyes10S UV-VIS, USA), bunsen, pillius, pipet ukur, blue tips, batang $\mathrm{L}$, spatula kaca.

\section{Metode/ pelaksanaan}

Pembuatan tepung labu kuning ini mengacu pada (Anggrahini, Ratnawati, \& Murdijati, 2006) dengan modifikasi. 
Mikroenkapsulasi bakteri pada penelitian ini mengacu pada (Kia, Alizadeh, \& Esmaiili, 2018) dengan modifikasi.
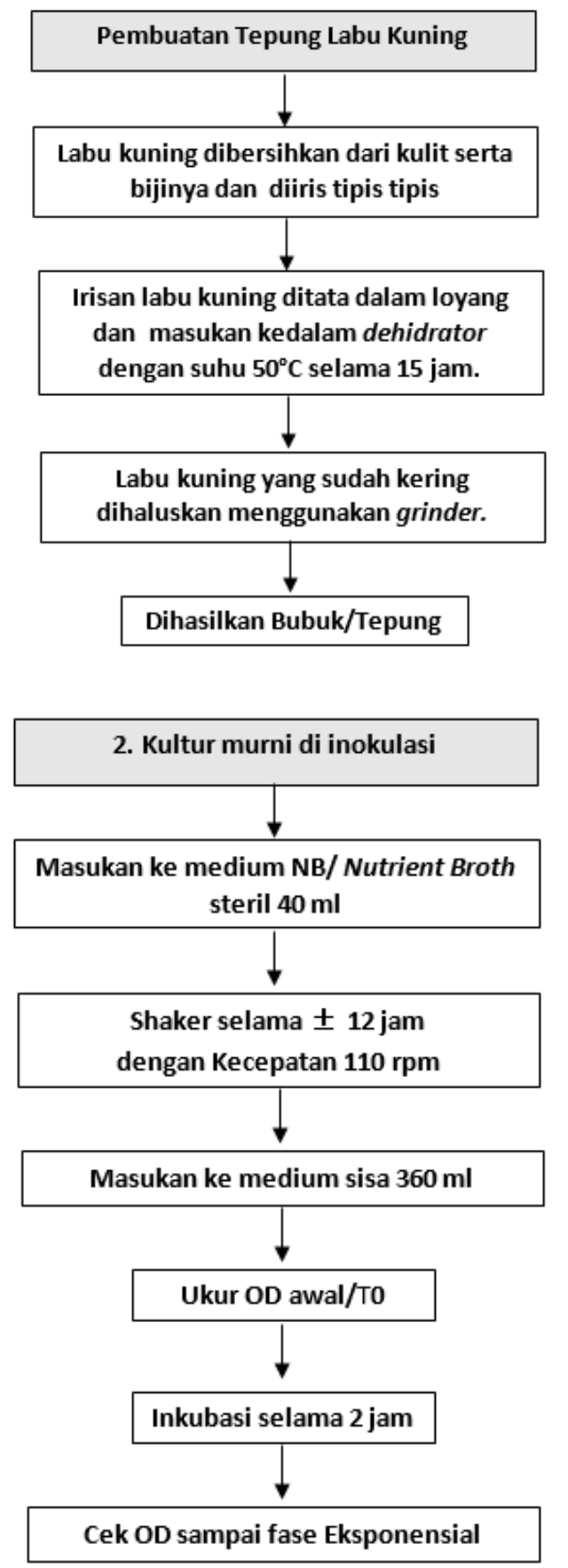

Pembiakan starter dilakukan dengan menggunakan starter bakteri Lactobaccilus sp dari merk Synbio.
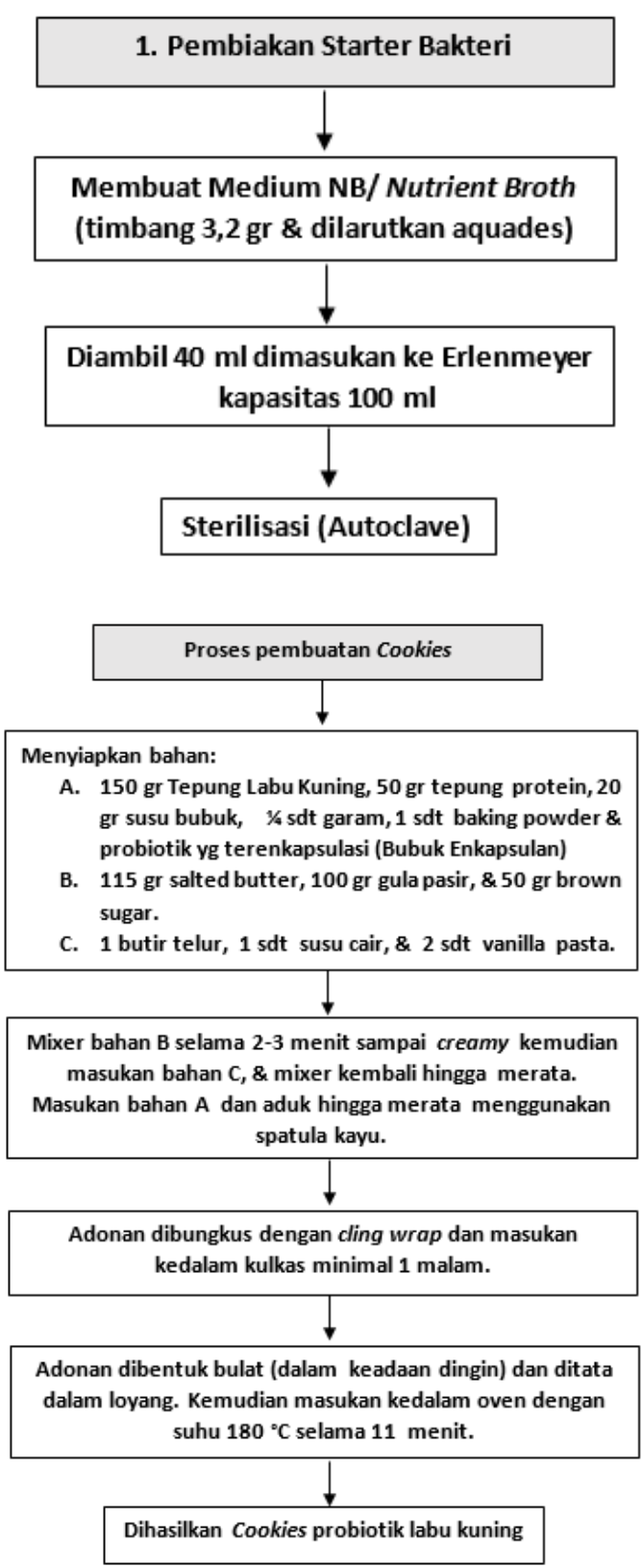


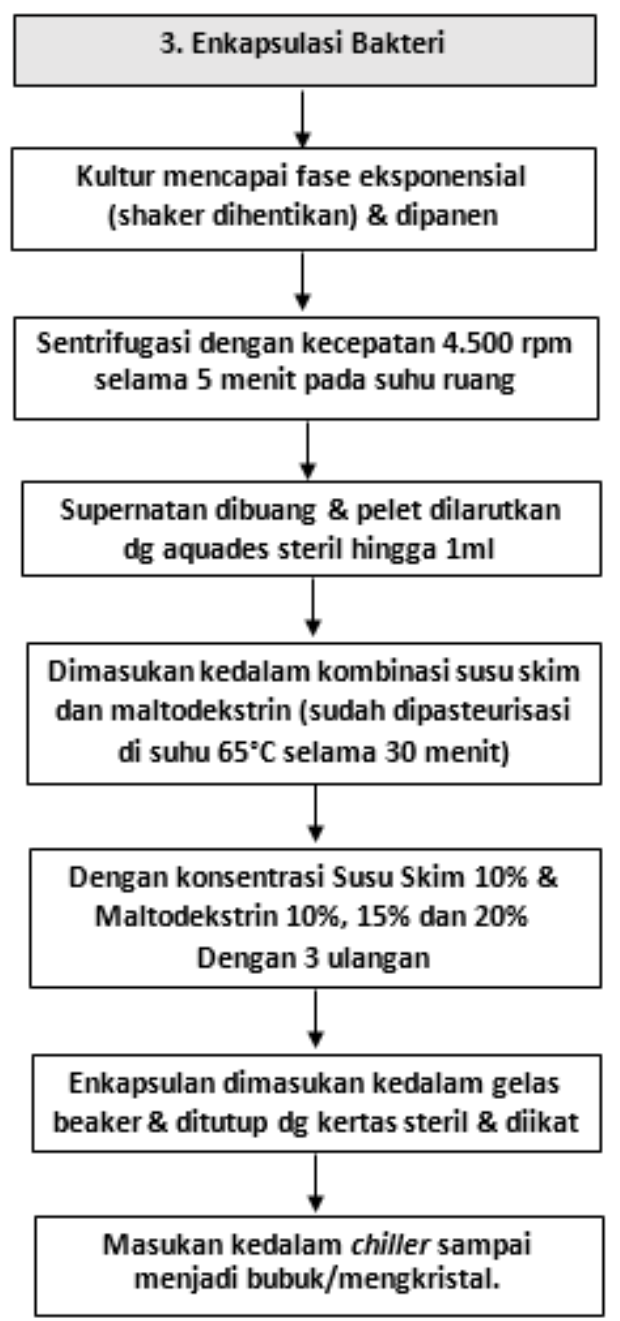

Gambar 1. Diagram alir metode pelaksanaan

Selanjutnya dilakukan perhitungan koloni yang tumbuh menggunakan coloni counter dan hasil yang didapatkan dapat di olah dengan metode TPC untuk menghasilkan perhitungan CFU (Colony Forming Unit), dengan rumus sebagai berikut;

$\mathrm{TPC}=\frac{\text { Jumlah koloni rata }- \text { rata }}{(\mathrm{ml}) \times(\text { faktor pengenceran })}=. . \quad \mathrm{CFU} / \mathrm{ml}$

Setelah itu menghitung viabilitas bakteri probiotik berdasarkan rasio jumlah bakteri per ml sesudah dan sebelum proses enkapsulasi dan dinyatakan dalam persen (\%) dengan rumus sebagai berikut;

Viabillitas $(\%)=$

$\frac{\text { Total probiotik sesudah enkapsulasi }}{\text { Total probiotik sebelum enkapsulasi }} \times 100 \%$

\section{Analisis data}

Pada penelitian ini data di uji menggunakan Uji One Way Anova pada SPSS 16, untuk mengetahui apakah terdapat perbedaan rata-rata viabilitas bakteri pada masing-masing perlakuan.

\section{HASIL DAN PEMBAHASAN}

\section{Peningkatan nilai OD larutan probiotik} pada inkubasi selama dua jam.

Pada pengkulturan murni bakteri Lactobacillus achidopilus dan Bifidobacterium logum ini dilakukan dengan memberikan waktu inkubasi 0,1 jam dan 2 jam didapatkan hasil Optical Density (OD) sebagai berikut: 
Tabel 1. Data perhitungan OD menggunakan spektrofotometer terhadap waktu inkubasi kultur murni.

\begin{tabular}{cccc}
\hline Perlakuan & \multicolumn{3}{c}{ Waktu inkubasi } \\
\cline { 2 - 4 } & T0 & T1 $(1$ jam $)$ & T2 $(2$ jam $)$ \\
\hline Konsentrasi 10\% & 0,325 & 0,432 & 0,460 \\
Konsentrasi 15\% & 0,404 & 0,445 & 0,452 \\
Konsentrasi 20\% & 0,398 & 0,439 & 0,459 \\
\hline
\end{tabular}

Pada tabel 1 diperlihatkan pada perlakukan konsentrasi penambahan bakteri asam laktat (probiotik) menunjukkan adanya peningkatkan nilai OD. Nilai OD dapat menunjukkan jumlah sel pada fase eksponensial dalam suspensi bakteri (Zhang et al., 2015). Adanya peningkatan nilai OD tersebut mencerminkan adanya pertambahan jumlah sel yang memengaruhi kekeruhan suspensi.

\section{Proses enkapsulasi bakteri Lactobacillus} achidopilus dan Bifidobacterium logum.

Pada proses enkapsulasi bakteri
Bifidobacterium logum ini, digunakan beberapa konsentrasi atau perlakuan penambahan kombinasi bahan penyalut, yaitu:

A. Susu skim $10 \%+$ maltodektrin $10 \%$, B. Susu skim $10 \%+$ maltodekstrin $15 \%$, C. Susu skim $10 \%+$ maltodekstrin $20 \%$.

Enkapsulasi ini dilakukan melalui proses pengeringan dengan menggunakan chiller, hingga enkapsulan menjadi bubuk/mengkristal dan didapatkan hasil seperti gambar dibawah ini:

\section{Lactobacillus achidopilus dan}

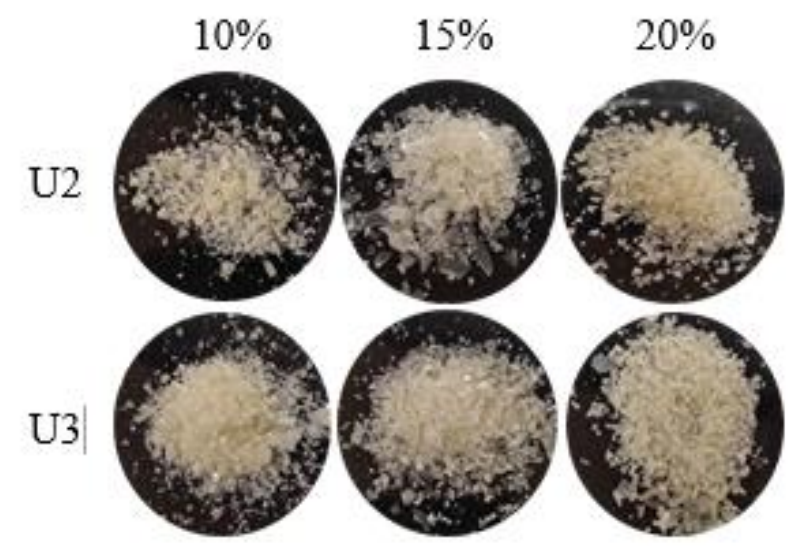

Gambar 1. Hasil produk mikroenkapsulasi bakteri

Keterangan:
U2 : Enkapsulan ulangan 2
U3 : Enkapsulan ulangan 3

Perhitungan koloni bakteri pada masingmasing konsentrasi menggunakan coloni counter.

Metode Spread plate yang dilakukan adalah pada medium NA pada enkapsulan hari ke-1, hari ke-3 dan pada hari ke-7 pada masing-masing perlakuan di setiap ulangan, untuk meghasilkan koloni bakteri yang diinginkan. Hasil perhitungan koloni bakteri dapat dilihat pada tabel dibawah ini; 
Tabel 3. Data perhitungan koloni di setiap ulangan pada masing-masing konsentrasi menggunakan coloni counter.

\begin{tabular}{|c|c|c|c|c|}
\hline Perlakuan & Ulangan & $\begin{array}{l}\text { Hasil Enkapsulasi } \\
\left(\text { hari ke-1) }\left(10^{-40}\right)\right.\end{array}$ & $\begin{array}{l}\text { Sisa Enkapsulasi } \\
\text { (hari ke-3) }\left(10^{-40}\right)\end{array}$ & $\begin{array}{c}\text { Bubuk/cookies } \\
\text { (hari ke-7) }\left(10^{-10}\right)\end{array}$ \\
\hline Konsentrasi & 1 & 25 & 46 & 44 \\
\hline $10 \%$ & 2 & 26 & 41 & 38 \\
\hline & 3 & 24 & 47 & 43 \\
\hline \multicolumn{2}{|c|}{ Rata-rata } & 25 & 45 & 42 \\
\hline Konsentrasi & 1 & 26 & 47 & 45 \\
\hline \multirow[t]{2}{*}{$15 \%$} & 2 & 25 & 44 & 43 \\
\hline & 3 & 29 & 49 & 47 \\
\hline \multicolumn{2}{|c|}{ Rata-rata } & 27 & 47 & 45 \\
\hline Konnsentrasi & 1 & 25 & 52 & 51 \\
\hline \multirow{2}{*}{$20 \%$} & 2 & 27 & 49 & 48 \\
\hline & 3 & 26 & 43 & 48 \\
\hline \multicolumn{2}{|c|}{ Rata-rata } & 26 & 48 & 49 \\
\hline
\end{tabular}

Perhitungan pada tabel diatas dilakukan pada setiap cawan petri yang dihitung satu persatu diatas coloni counter. Hasil enkapsulasi adalah bakteri yang sudah dienkapsulasi pada hari ke-1 sebelum dimasukan kedalam chiller yang kemudian di spread plate untuk mendapatkan hasil koloni yang diinginkan. Sisa enkapsulasi yang dimaksudkan adalah enkapsulan yang sudah dimasukan ke dalam chiller dan didiamkan selama 3 hari sampai menjadi bubuk/mengkristal. Bubuk/cookies adalah enkapsulan yang sudah berada didalam chiller dan sudah mengkristal, yang nantinya akan dimasukan kedalam adonan cookies yang kemudian di spread plate kembali untuk mendapatkan hasil koloni yang diinginkan. Hasil perhitungan yang didapatkan dari masing-masing ulangan dirata-rata. Pada penelitian ini, proses pengeringan enkapsulan yang dimasukan kedalam chiller, membutuhkan waktu selama 7 hari untuk mendapatkan hasil bubuk enkapsulan. Pengenceran pada hasil enkapsulasi dan sisa enkapsulasi berbeda dengan pengenceran sesudah menjadi cookies, hal ini dikarenakan enkapsulan yang dimasukan kedalam adonan cookies sudah melewati proses pengeringan dan pemanggangan. Sehingga kemungkinan terdapat bakteri yang hilang kestabilannya untuk bertahan hidup, oleh karena itu pada saat digunakan pengenceran $10^{-40}$ jumlah koloni yang tumbuh lebih sedikit dibandingkan dengan pengenceran $10^{-10}$.

Berdasarkan pada hasil yang didapatkan pada tabel 3 bahwa, hasil enkapsulasi pada hari pertama diperoleh jumlah koloni yaitu < 30. Hal ini menunjukan bahwa, koloni yang tumbuh terlalu kecil atau sedikit dan tidak memenuhi standart perhitungan koloni. Standart koloni adalah 30-300 koloni. Tetapi jumlah koloni tersebut tetap dapat dihitung, karena Cawan petri yang dihitung adalah cawan petri yang memiliki jumlah koloni bakteri $25-250$ koloni bakteri. Hal ini diperkuat oleh penelitian (Hartati, 2013) yang menunjukkan bahwa perhitungan jumlah koloni bakteri dilakukan pada cawan yang mengandung 25 hingga 250 koloni bakteri sesuai dengan SNI 01-2332.3-2006 tentang pengujian angka lempeng total.

Dapat dilihat juga pada tabel 3, penurunan sel bakteri kemungkinan disebabkan oleh adanya proses pengeringan. Pada keadaan enkapsulan berada dalam chiller yang dapat mengakibatkan sel kehilangan kestabilannya. Conde-Islas et al., (2019) menyebutkan bahwa proses pengeringan pada suhu rendah dapat menyebabkan penurunan daya tahan bakteri apabila dilakukan terlalu lama sebab bakteri akan lebih lama terpapar faktor lingkungan. Sementara menurut (Ray, 1993 dikutip, (Puspawati, Nuraida, \& Adawiyah, 2010)), paparan faktor lingkungan berlebih dapat menyebabkan shock osmotik dengan 
ditandai oleh kerusakan membran dan ikatan oksigen yang dapat berpengaruh pada sifatsifat makromolekul hidrofilik dalam sel.

Mikroenkansulasi

Bakteri

Lactobacillus achidopilus dan

Bifidobacterium logum dengan penambahan konsentrasi kombinasi penyalut pada perlakuan $\mathrm{A}$ dan $\mathrm{B}$, mengalami penurunan sel kemungkinan pada saat proses pemanggangan. Proses pemanggangan dengan suhu tinggi dapat menyebabkan bakteri mati. Paparan suhu tinggi pada bakteri dapat menyebabkan kerusakan membran sel yang menyebabkan bocornya sitoplasma tanpa mengalami lisis (Ebrahimi, Csonka, \& Alam, 2018). Pada perlakuan A dan B, konsentrasi penyalut belum mampu melindungi bakteri dari paparan panas sehingga bakteri mengalami kematian akibat kerusakan membran sel.

Tabel 4 Data perhitungan CFU bakteri menggunakan metode TPC.

\begin{tabular}{ll}
\hline & Perlakuan \\
& $\mathrm{A}$ \\
$\mathrm{B}$ & \\
$\mathrm{C}$ & \\
& \\
Keterangan: \\
$\mathrm{A} \quad$ : Konsentrasi kombinasi bahan penyalut $10 \%$ \\
$\mathrm{~B} \quad$ : Konsentrasi kombinasi bahan penyalut $15 \%$ \\
$\mathrm{C} \quad$ : Konsentrasi kombinasi bahan penyalut $20 \%$
\end{tabular}

Hasil perhitungan CFU menunjukkan bahwa seluruh perlakuan mampu mempertahankan probiotik hingga memenuhi batas minimum jumlah probiotik dalam makanan yaitu $\left(10^{6}\right) \mathrm{CFU} / \mathrm{g}$ (Terpou et al., 2019). Setelah didapatkan hasil perhitungan CFU (Colony Forming Unit),

\section{Penentuan viabilitas menggunakan} metode kuantitatif.

Menghitung koloni yang tumbuh menggunakan metode TPC dan menghitung viabilitas bakteri probiotik berdasarkan rasio jumlah bakteri per ml sesudah dan sebelum proses enkapsulasi dan dinyatakan dalam persen $(\%)$.

Pada perhitungan menggunakan metode TPC ini data yang diambil adalah rata-rata probiotik yang sudah dienkapsulasi (Cookies), pada masing-masing konsentrasi disetiap ulangan. Berdasarkan pada perhitungan rata-rata koloni bakteri sesudah menjadi cookies, pada perlakuan konsentrasi $10 \%$ sebanyak 42 koloni bakteri, konsentrasi $15 \%$ sebanyak 45 koloni bakteri dan pada perlakuan konsentrasi 20\% sebanyak 49 koloni bakteri. Didapatkan hasil perhitungan seperti pada tabel di bawah;

achidopilus dan Bifidobacterium logum Sesudah dienkapsulasi (cookies)

$4,2 \times 10^{12} \mathrm{CFU} / \mathrm{ml}$
$4,5 \times 10^{12} \mathrm{CFU} / \mathrm{ml}$
$4,9 \times 10^{12} \mathrm{CFU} / \mathrm{ml}$

$4,5 \times 10^{12} \mathrm{CFU} / \mathrm{ml}$

$4,9 \times 10^{12} \mathrm{CFU} / \mathrm{ml}$

pengujian viabilitas dilanjutkan dengan menghitung prosentase bakteri Lactobacillus achidopilus dan Bifidobacterium logum. Dengan total probiotik sebelum enkapsulasi sebanyak 5 milyar CFU (5x $\left.10^{12}\right)$. Hasil yang didapatkan dapat dilihat pada tabel 5 .

Tabel 5. Data viabilitas (\%) pada penambahan kombinasi bahan penyalut terhadap bakteri Lactobacillus achidopilus dan Bifidobacterium logum.

\begin{tabular}{cc}
\hline Perlakuan & Rata-rata Viabilitas (\%) \\
\hline A & $84 \%$ \\
B & $90 \%$ \\
C & $98 \%$ \\
\hline
\end{tabular}

\section{Keterangan:}

A : Konsentrasi kombinasi bahan penyalut $10 \%$

B : Konsentrasi kombinasi bahan penyalut $15 \%$

C : Konsentrasi kombinasi bahan penyalut $20 \%$ 
Berdasarkan hasil pada tabel 5, dapat dilihat bahwa mikroenkapsulasi bakteri Lactobacillus achidopilus dan Bifidobacterium logum dengan penambahan konsentrasi kombinasi penyalut $10 \%$ susu skim dan $20 \%$ maltodekstrin menghasilkan viabilitas terbaik yaitu viabilitas sel $98 \%$.
Analisis data menggunakan uji one way ANOVA

Data diolah dengan menggunakan SPSS 16 dan didapatkan hasil seperti diagram dibawah ini;

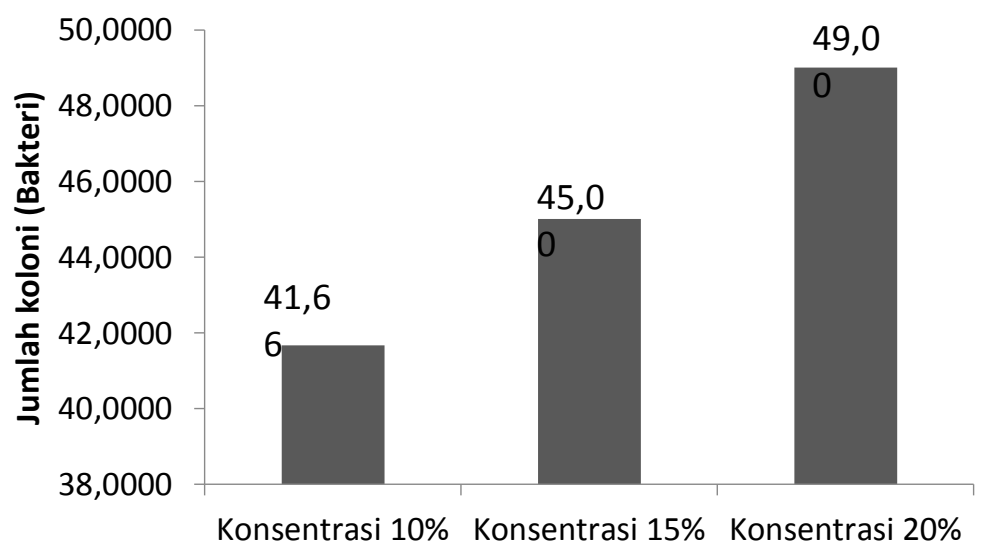

Perlakuan

Gambar 3. Hasil perhitungan jumlah koloni bakteri pada berbagai perlakuan.

Berdasarkan pada diagram diatas, yang menunjukkan bahwa viabilitas bakteri Lactobacillus achidopilus dan Bifidobacterium logum pada perlakuan A dan B tidak beda nyata dan pada perlakuan C beda nyata. Hal ini menunjukkan bahwa semakin tinggi penambahan maltodekstrin yang dikombinasikan dengan susu skim $10 \%$, menghasilkan viabilitas sel bakteri yang tinggi. Maltodekstrin memiliki sifat thermo protective mampu melindungi sel bakteri dari kerusakan akibat suhu ekstrim lingkungan (Arepally, Reddy, dan Goswani, 2020). Selain itu, penggunaan konsentrasi maltodekstrin yang semakin tinggi menghasilkan viabilitas yang semakin tinggi juga.

Hasil pengujian ini sesuai dengan hasil penelitian yang dilakukan oleh (Sumanti, Kayaputri, Hanidah, Sukarminah, \& Giovanni, 2016), yang menunjukkan bahwa semakin tinggi konsentrasi penyalut maka efisiensi enkapsulasi semakin meningkat dan memperkuat lapisan kulit. Sehingga dapat melindungi bahan inti dengan baik dan dapat melindungi zat yang mudah menguap ketika proses pengeringan berlangsung, yang dapat menyebabkan retensi bahan inti akan semakin meningkat. Tetapi, jumlah penyalut yang terlalu tinggi juga dapat menyebabkan suspensi menjadi kental sehingga dapat menyulitkan proses atomisasi. Penyalut yang digunakan terlalu tinggi juga dapat menyebabkan pembengkakan (puffing) atau penggelembungan (balloning) serta keretakan partikel yang mengakibatkan turunnya retensi bahan inti.

\section{KESIMPULAN}

Berdasarkan dari hasil yang didapatkan, dapat disimpulkan bahwa Lactobacillus achidopilus dan Bifidobacterium logum pada perlakuan A dan B tidak beda nyata dan perlakuan $\mathrm{C}$ beda nyata. Hal ini menunjukkan bahwa semakin tinggi penambahan maltodekstrin yang dikombinasikan dengan susu skim 10\%, menghasilkan viabilitas sel bakteri yang tinggi. Mikroenkapsulasi bakteri Lactobacillus achidopilus dan Bifidobacterium logum dengan penambahan konsentrasi kombinasi penyalut $10 \%$ susu skim dan $20 \%$ maltodekstrin menghasilkan 
viabilitas terbaik yaitu viabilitas sel $98 \%$. Oleh karena itu, peneliti selanjutnya diharapkan untuk menguji daya simpan cookies terhadap ketahanan viabilitas bakteri jika cookies disimpan dalam waktu yang lama.

\section{UCAPAN TERIMA KASIH}

Ucapan terima kasih kepada semua pihak yang telah mendukung terlaksanya penelitan ini, serta Fakultas Biologi, Universitas Kristen Satya Wacana, Salatiga, Jawa Tengah yang telah memberikan wadah untuk melaksankan penelitian.

\section{DAFTAR PUSTAKA}

Anggrahini, S., Ratnawati, I., \& Murdijati, A. (2006). Pengkayaan $\beta$-Karoten Mi Ubi Kayu Dengan Tepung Labu Kuning (Cucurbita maxima Dutchenes). Majalah Ilmu dan Teknologi Pertanian, 81-82.

Arepally, D., Reddy, R, S., and Goswami, T, K. (2020). Studies on survivability, storage stability of encapsulated spray dried probiotic powder. Curr. Res. Food Sci., 3(2020), 235-242. https//: doi.org/10.1016/j.crfs.2020.09.001.

Conde-Islas, A, A., Jimenez-Fernandez, M., Cantu-Lozano, D., Urrea-Garcia, G, R., and Luna-Solano, G. (2019). Effect of the freeze-drying process on the physicochemical and microbiological properties of Mexican kefir grains. Processes.7(3). https//: doi.org/10.3390/pr7030127.

Ebrahimi, A., Csonka, L, N., \& Alam, M, A. (2018). Analyzing Thermal Stability of Cell Membrane of Salmonella Using Time-Multiplexed Impedance Sensing. Biophys. J. 114(3), 609618.

https://doi.org/10.1016/j.bpj.2017.10. 032.

Hamidah, S. (2015). Sayuran dan Buah Serta Manfaatnya Bagi Kesehatan Disampaikan dalam Pengajian
Jamaah Langar Mafaza Kotagede Yogyakarta. Fakultas Teknik Universitas Negeri Yogyakarta, 1-10.

Hartati, F. K. (2013). Evaluasi Metode Pengujian Angka Lempeng Total Menggunakan Metode Petrifilm Aerobic Count Plate Terhadap Metode Uji SNI 01.2332.2006 Pada Produk Perikanan Di LPPMHP Surabaya. Jurnal Teknik Industri HEURSTIC 2, 13(2), 89-105.

Hawa, A., Satheesh, N., \& Kumela, D. (2018). Nutritional and antinutritional evaluation of cookies prepared from okara. International Food Research Journal, 25(5), 20422050.

Husniati. (2009). Studi Karakterisasi Sifat Fungsi Maltoedekstrin dari Pati Singkong. Jurnal Riset Industri 3(2), 133-138.

Kia, E. M., Alizadeh, M., \& Esmaiili, M. (2018). Development and characterization of probiotic UF Feta cheese containing Lactobacillus paracasei microencapsulated by enzyme based gelation method. $J$. Food Sci Technol. 55(9), 3657-3664.

Kusumayanti, H., Hanindito, S. B., \& Mahendrajaya, R. T. (2016). Pangan Fungsional dari Tanaman Lokal Indonesia. Metana, 12(1), 26-30.

Mustika, A. R., \& Kartika, W. D. (2020). Formulation of yellow pumpkin cookies with mocaf (modified cassava flour) flour addition as a snack for the obese community. Food Research 4(Suppl. 3), 109-113.

Puspawati, N. N., Nuraida, L., \& Adawiyah, D. R. (2010). Penggunaan Berbagai jenis Bahan Pelindung untuk Mempertahankan Viabilitas Bakteri Asam Laktat yang di Isolasi dari Air Susu Ibu pada Proses Pengeringan Beku. Jurnal Teknologi dan Industri Pangan 21(1), 59-65.

Puspita, D., \& Samalukang, Y. (2017). Termostabilitas Antosianin dari Buah Basella Rubra yang Dimikroenkapsulasi. Jurnal 
Teknologi Pangan dan Hasil

Pertanian.

Samedi, L., \& Charles, A. L. (2019). Viability of probiotic bacteria mikroenncapsulated with arrowort starch in the simulated gastrointestinal tract (GIT) and yoghurt. MDPI, 8-175.

Setyowati, \& Khomah, I. (2016). Pengembangan Agrobisnis Waluh Getasan Kecamatan Getasan Kabupaten Semarang. Jurnal SEMAR 5 .

Sumanti, D., Kayaputri, I. L., Hanidah, I.-i., Sukarminah, E., \& Giovanni, A. (2016). Pengaruh Konsentrasi Susu Skim dan Maltodekstrin Sebagai Penyalut Terhadap Viabilitas dan Karakteristik Mikroenkapsulasi

Suspensi Bakteri Lactobacillus plantarum menggunakan metode freeze drying. Jurnal Penelitian Pangan (Indonesian Journal of Food Research) 1(1), 7-13.

Terpou, A, A., Papadaki, Lappa, I, K., Kachrimanidou, V., Bosnea, L, A., \& Kopsahelis, B. (2019). Nutrients. 11(7), 32.

Widiyaningsih, E. N. (2011). Peran Probiotik untuk Kesehatan. Jurnal Kesehatan. 4(1), 14-20.

Zhang, X., Wang, Y., Guo, J., YU, Y., Li, J., Guo, Y., \& Liu, C. (2015). Comparing two functions for optical density and cell numbers in bacterial exponential growth phase. J. Pure Appl. Microbiol. 9(1), 299-305. 